\title{
Theological training in the black Reformed Churches in South Africa (RCSA)
}

\author{
Author: \\ Hulisani Ramantswana ${ }^{1}$ \\ Affiliation: \\ ${ }^{1}$ Biblical and Ancient Studies, \\ University of South Africa, \\ South Africa \\ Correspondence to: \\ Hulisani Ramantswana \\ Email: \\ ramanh@unisa.ac.za \\ Postal address: \\ PO Box 392, UNISA 0003, \\ South Africa \\ Dates: \\ Received: 03 Mar. 2014 \\ Accepted: 21 Oct. 2014 \\ Published: 31 Mar. 2015 \\ How to cite this article: \\ Ramantswana, H., 2015, \\ 'Theological training in the \\ black Reformed Churches in \\ South Africa (RCSA)', In die \\ Skriflig 49(1), Art. \#1814, \\ 17 pages. http://dx.doi. \\ org/10.4102/ids.v49i1.1814

\section{Copyright:} \\ C 2015. The Authors. \\ Licensee: AOSIS \\ OpenJournals. This work is \\ licensed under the Creative \\ Commons Attribution \\ License.
}

Read online:
This article presents a historic analysis of theological training in the black Reformed Churches in South Africa (RCSA) - Southland Synod (Coloured), Synod Midlands (black) and Synod Soutpansberg (black) - and highlights the major trends with regard to theological training. Four phases are identified: (1) 1910-1951, informal training of evangelists and ministers on a local basis; (2) 1952-1960, the beginning of formal training of ministers and evangelists; (3) 1961-1989, training under the 1961 Theological Training Policy for the black RCSA; and (4) 1990 to today, theological training in the black RCSA in the context of the new South Africa.

Teologiese opleiding in die swart Gereformeerde Kerke in Suid-Afrika (GKSA). Die artikel bied ' $n$ historiese ontleding van teologiese opleiding in die swart Gereformeerde Kerke in Suid-Afrika - Suidland Sinode (Kleurling), Middellande Sinode (swart) en Soutpansberg Sinode (swart) - en beklemtoon die belangrikste tendense met betrekking tot teologiese opleiding. Vier fases word in die artikel geïdentifiseer: (1) 1910-1951, informele opleiding van evangeliste en leraars op 'n plaaslike basis; (2) 1952-1960, die begin van die formele opleiding van predikante en evangeliste; (3) 1961-1989, opleiding onder die 1961 Teologiese Opleidingsbeleid in die swart GKSA; en (4) 1990 tot vandag, teologiese opleiding in die swart GKSA in die konteks van die nuwe Suid-Afrika.

\section{Introduction}

This article presents a historic analysis of theological training in the black Reformed Church in South Africa. ${ }^{1}$ Beginning in 1963, the RCSA was composed of four national synods: Potchefstroom (white), ${ }^{2}$ Suidland/Southland (mixed race), ${ }^{3}$ Middellande/Midlands (black), ${ }^{4}$ and Soutpansberg (black). ${ }^{5}$ The General Synod of the four national synods was functional only during the apartheid era, meeting six times (1965, 1975, 1980, 1984, 1988 and 1992), and has since been nonfunctional. The racial tag 'black' is used in two senses: firstly, to refer to the three national synods (Southland, Midlands and Soutpansberg) and, secondly, to highlight the reality of the history of the RCSA and the legacy of apartheid in South Africa, which was also exhibited in the church. Theological training in the RCSA was done along racial lines - there was theological training for black people and there was theological training for white people until 1994. Four phases are distinguishable in the history of the black RCSA relating to theological training: the first phase was from 1910 to 1951, the second from 1952 to 1960, the third from 1961 to 1989, and the fourth from 1990 to the present.

\section{First phase (1910-1951): Informal training of evangelists and ministers on a local basis}

The first phase of theological training within the black RCSA was intertwined with the mission efforts by the white sister churches that began in 1910. One year earlier, in 1909, the GKSA celebrated 50 years of existence, and the theological school celebrated 40 years of formal theological training (see Du Plooy 2003:490). Theological training in the black RCSA was necessitated by the missionaries' need for assistance from the indigenous people in the transmission of the gospel,

\footnotetext{
1.The Reformed Church in South Africa (RCSA) is also commonly known by its Afrikaans name: Gereformeerde Kerke in Suid-Afrika (GKSA).

2.The abbreviation GKSA will be used to refer to the white synod, that is, the Gereformeerde Kerk in Suid-Afrika Potchefstroom Nasionale Sinode.

3.From now on, RCSASKNS will be used as an abbreviation for the Reformed Church in South Africa Southland National Synod.

4.From now on, RCSAMNS will be used as an abbreviation for the Reformed Church in South Africa Midlands National Synod.

5.From now on, RCSASNS will be used as an abbreviation for the Reformed Church in South Africa Soutpansberg National Synod.
} 
as well as church-planting efforts. Theological training began with the training of the 'helpers' (evangelists) and later developed to include training of ministers.

\section{Training of evangelists}

In this initial phase, theological training of the evangelists was intertwined with mission. In the GKSA, mission work amongst black people officially began in 1910 with Reverend Pieter Bos, whose work was focused on Northern Transvaal now Limpopo Province (GKSA 1953). ${ }^{6}$ In order for white missionaries to penetrate the mission areas, it was necessary for them to work and cooperate with the people they wanted to evangelise. It was deemed necessary for the missionaries to have helpers or evangelists to assist them in the work. The work of the missionary was regarded as analogous to that of the apostles (GKSA 1973):

The missionary's task is analogous to that of apostle, but not identical. We must distinguish between the mission and the permanent office of the Word. The mission finds its purpose in holy baptism, while the office of the Word is the outworking of the baptism. (p. 21, [author's own translation])

At the earliest stage, the role of the evangelist was literally to assist the white missionary by mediating between the missionary and the people as an interpreter. The evangelist was at the service of the missionary and did not function independently to any great extent in the proclamation of the gospel. Later, the role of evangelist came to include the proclamation of the gospel and organisation of the church in assistance to the missionary. In this setup, the white missionaries also functioned as supervisors of the evangelists (GKSA 1973:25).

In the Northern Transvaal, Reverend Bos was first stationed at Molietsieskop, which was a district in what was then Pietersburg (now known as Polokwane) before proceeding further north to Uniondale. The first black evangelists were from Uniondale. Bos took a young man, Jojakim Matlakala, who was initially part of the Lutheran Mission Church, and started training him as an evangelist: teaching him to read and write in Afrikaans, and taking him to live with him and help him with the household chores. Matlakala lived with Bos until 1919, when he decided to go find greener pastures elsewhere. ${ }^{7}$ Matlakala returned to Uniondale in 1923, only to find that Bos had passed away just a few months earlier (see GKSA 1953:7). Other evangelists who worked alongside Bos at Uniondale and Molietsieskop were Manasseh Moshapo and Isaiah Moutlwatse. Moshapo's ministry was focused at Uniondale, whereas Moutlwatse's ministry was focused at Molietsieskop. Following the death of Bos in 1923, these men

6.Reverend Pieter Bos did not undergo formal theological training, but was ordained as a minister of the RCSA in accordance with Article 8 of the Church Order of the RCSA, which allows for those who have extraordinary gifts to be permitted to take the office of minister of the Word without having necessarily undergoing the forma training. It is interesting to note that the first missionary of the white RCSA had no formal theological training, considering that theological training within the white RCSA was started in 1869. This makes one wonder about the scope of theological education within the RCSA from 1869 to 1909.

7.Between 1919 and 1923, Matlakala went to work at Premier Mine (the Cullinan diamond mine was also known as such) and other diamond mines in Bloemhof Pretoria and Pietersburg (GKSA 1953:7). played an important role in ensuring continuity of the church in these two locations (GKSA 1953:10).

In 1928 Reverend Hugo du Plessis took over the work begun by Bos, ${ }^{8}$ later proceeding further north with evangelist Matlakala and building a mission station at Siloam. Matlakala quickly learned Tshivenda and soon started a children's ministry. Back at Molietsieskop, Isaiah Moutlwatse passed away in 1929 and was succeeded as evangelist by his son, Andries (see GKSA 1953:9).

When the mission field expanded in the Venda area, there was a need for more evangelists. Du Plessis outsourced help from the Nederduitse Gereformeerde Kerk (NGK) of South Rhodesia, which sent six evangelists. The record shows that in 1942 there were six evangelists: Jojakim Matlakala and five of those sent by the NGK, known only as Joseph, Shadrack, Ezekiel, Paulus and Aaron (GKSA 1953:12). ${ }^{9}$ In 1942, Reverend J.F. Erasmus was sent as a missionary to De Hoop (also called Karamel), where a new mission station was established. In addition to the mission stations, many more preaching points were established. Consequently, the demand for evangelists to work alongside the missionaries also increased. By 1949, the following evangelists were serving in the Venda area (see GKSA 1949:93-94, 98):

- Jojakim Matlakala (as minister of Siloam).

- Manasseh Moshapo (Uniondale).

- Stefaans (Witvlag).

- Johannes (Tshithuthuni).

- Joseph (Tshiendeulu).

- Aaron (Pisanghoek).

- Willem (Bergplaas).

- Shadrack (Swartfontein).

- Richard (Thononda).

- Elias (Sane).

- Jonias (Sterkwater).

- Ezekiel (Hangklip).

- Paulus (Mopani).

- Andries (Soutpan).

- Frans (Pisangkop).

- Joni and Salmon (Diepkloof).

- Daniel (De Hoop).

- Samson (Tswera).

- Amos (Vhurivhuri).

- Thomas (Mabila).

- Alpheus (Tshamulungwi).

- Daniel (Gogogo).

However, during this time some missionary activities were also taking place in other parts of the country: the central part (Rand area: Springs, Benoni); in the west at Durban there were initiatives to start with mission work at Lamontville;

8.For more on the contribution of Hugo du Plessis to the mission of the GKSA, see Mashau (2004)

9.The tendency during the colonial-apartheid era was for black people to simply be The tendency during the colonial-apartheid era was for black people to simply be
called by personal names, without making reference to their family names. This called by personal names, without making reference to their family names. This
tendency is also observable at Die Nasionale Vrouemonument in Bloemfontein at the section that portrays the agteryers [behind riders], referring to the black people who assisted the Afrikaners in the Anglo-Boer War. 
and in the Cape there was on-going work in Venterstad and Philipstown (GKSA 1949). By 1951, the following black churches had been established: Venterstad or Lyciumville (1896), Soutpansberg (1942), Philipstown (1944), Kwa-Thema or Springs (1949), and Natalspruit or Katlehong (1950).

At this stage, the work of the evangelist was no longer confined to simply being in the service of the missionary. The evangelist had to play an even greater role in the proclamation of the gospel and organising the church in different areas, and so, although still under the supervision of the missionary, the evangelists were gradually becoming more independent in executing their duties. The missionary task involved training or equipping those who served with the missionary as evangelists. However, the training of evangelists in this phase was not formal; rather, it was the task of the missionary on a local basis.

\section{From evangelist to minister of the Word: Jojakim Matlakala}

In 1946, the evangelist Jojakim Matlakala expressed desire and willingness to be trained as a minister of the Word. This was a watershed moment that signalled a need for a shift, not simply in mission, but also in theological training. The GKSA had to start contemplating and developing theological training for the mission churches. Matlakala started receiving training for the ministry of the Word in accordance with the study programme approved by the GKSA synod deputies. After a year and half of studies, he completed his training. In June 1947, the GKSA synod mission deputies examined him, and he was considered worthy to be called as a minister of the Word. On 08 October 1947, Matlakala was ordained as a minister of Soutpansberg Reformed Church, thus becoming the first black minister of the Word in the RCSA (GKSA 1953:13).

Beginning in 1947 there was a sense that mission had reached a point where it was necessary to organise formal training for ministers of the Word and evangelists. The willingness of evangelist Matlakala to transition from evangelist to minister of the Word signalled a need for structured and formal theological training. However, the facilitation of such a transition could not be solely the task of the missionary, so the GKSA entrusted synod mission deputies with the responsibility of managing the transition. Furthermore, in accordance with the GKSA Church Order Articles 4 and 5 , the calling and admission to the office of minister of the Word required the involvement of other church structures, the church council, and the classis and/or synod for the black churches that were being planted.

\section{Second phase (1952-1960): The beginning of formal training of ministers of the Word and evangelists}

The beginning of the formalisation of theological training of ministers of the Word and evangelists was intertwined with the move of. Du Plessis from the Venda area to Soweto, a black township, which was the hub of migrant labourers. The move to start with formal theological training of black people was intertwined with what the mission deputies of GKSA called Groot Spelonken, an area between present day Modjadjiskloof and Louis Trichardt. The deputies of mission of GKSA (GKSA 1949) wrote:

\begin{abstract}
So het ons sendingswerk met hierdie derde sendingsveld nog 'n ander mylpaal bereik. Mag die opleidingskool spoedig opgerig word om die naturelle-leraars en -helpers aan ons sendingsleraars te verskaf sodat die Woord van God sy loop mag hê. Laat ons die geopende deure oophou! [In this third phase, our mission task has reached yet another milestone. May we soon erect a training school for the native ministers and evangelists in order to support our missionaries so that the Word of God can run its course. Let us ensure that this open door remains open!] (p. 100, [author's own translation])
\end{abstract}

Theological training of black ministers of the Word and evangelists within the RCSA started moving forward; it was formalised in 1952 at Moroka (GKSA 1953:25). During this time there were six candidates trained as evangelists and seven candidates being trained as ministers (GKSA 1953:25). In 1955 a formal decision was taken to engage in formal theological training of black ministers and evangelists. This formal training began in 1956 at Dube under the leadership of Du Plessis. In 1962 the theological school moved to Hammanskraal and consequently was named Hammanskraalse Teologiese Skool [Hammanskraal Theological School (HTS)].

The establishment of a separate theological school for black people has to be viewed against the socio-political situation of the time. In 1959 the government established the Extension of University Education Act, which was also known as the Fort Hare Act. This act prohibited black people from studying at historically white universities, except with express permission of the government. The establishment of a theological school for black people implied that they would not be trained with white candidates for the ministry of the Word at the Teologiese Skool van Potchefstroom (TSP) at Potchefstroomse Universiteit vir Christelike Hoër Onderwys - an institution that started as a theological school of the GKSA in 1869 .

In 1959, when the white reformed churches or GKSA celebrated 100 years of existence, the black theological school at Dube had, from a total of 27 students, 17 black as well as two coloured students who were being trained as ministers of the Word, and eight who were being trained as evangelists, (Du Plessis 1959:128). This was a significant achievement, considering that formal training of black ministers of the Word had only started seven years earlier. From a mission perspective, many of the black churches that were planted from 1952 to 1961 would have the benefit of having full-time ministers at their service. ${ }^{10}$

10.The period of 1952 to 1961 is one in which there was an exponential growth, as many of the black churches were planted during this period. 
By 1961 a substantial number of ministers of the Word were already serving:

- E.J. Matlakala (who began in 1947 at Wildebeespan).

- W. Motšoane (died 1959).

- J. Matlakala Jr. (until 1960).

- C. Khoza (1958 at Dube).

- S.R. Madia (1957 at Natalspruit).

- D.V. Mahole (1957 at Lichtenburg, Ditsobotla).

- J.A. Lebitsa (1958 at Kwa-Thema/Springs).

- S. Seadira (1958 at Potchefstroom).

- S. M. Mugeri (1959 at De Hoop).

- E.J. Motau (1959 at Temba/Hammanskraal).

- D.F. Modiba (at Benoni/Boksburg).

- E.T. Chaka (1961 at Vereeniging, Sharpeville).

- E.E. Tladi (at Odendaalsrus).

- R. Moloi (at Vlakfontein).

- S.R. Madia (at Natalspruit).

- P. Silas (at Strubensvallei).

- D.L. Dingaka (at Ventersdorp).

- J. Dlamini (at Kwa-Mashu).

- J.P. Matsoso (at Waterkloof).

- P. Nkosi (at Dobsonville/Roodepoort).

- J.G. Moseki (at Mafikeng).

- S. Maas (at Sannieshof).

- Lakay (at Grassy-Park).

- J.W. Matthysen (at Newclare).

\section{The first Black lecturer: Reverend C. Khoza}

In 1957 the proponent C. Khoza, who was later pastor of Dube Reformed Church, was appointed to assist Du Plessis with the training of evangelists. Khoza served in this role until 30 November 1961 (GKSA 1962:4). The ministry of Khoza as a lecturer came to an end for two reasons, inter alia, the formal training of evangelists was discontinued (Botha 1994:6), and the appointment of black people at the theological seminary receded, as only white professors were appointed for the training of black ministers.

The appointment of Khoza was a positive move, which would have greatly enhanced the capacity of black ministers theologically. It is regrettable that Khoza's role as lecturer of evangelists came to an end when the training of evangelists was phased out from the theological school. No black lecturer or professor was appointed at this school again before its closure in 1994.

\section{Requirements and curriculum for study as evangelist and ministers}

In 1952 the admission requirements for those who were trained as evangelists or ministers was standard six or higher, ideally standard eight. The duration of study was three or four years, depending on the program followed (GKSA 1953:23). The following courses were offered to the students: dogmatics, ethics, homiletics and church history. The languages used for the training were Afrikaans, English and Sotho. The curriculum also included exposition of
Scripture verse by verse and practical work, such as house visitations and outreach (GKSA 1973:42-43).

The academic requirement continued to be raised as the years progressed. Beginning in 1962, the requirement for training at HTS was a senior certificate, although exceptions were still allowed. During this time study through correspondence was not accepted; the training only catered to full-time students. In 1970, a decision was made for students to complete their studies with a theological degree. However, HTS did not have an accredited programme at the time, so various options were explored in order to ensure that students were able to complete with a degree. In 1973 it was thought that seeking cooperation with institutions such as the University of South Africa or the University of the North would put the training in jeopardy, as HTS still wanted to maintain its relationship with Potchefstroom University (GKSA 1973).

\section{Phasing out and continuity of evangelist training}

As the office of pastor became more prominent, the office of evangelist became less so. In 1958 arguments were made from within the GKSA to phase out the training of evangelists. The role and task of an evangelist was described in contrast to the office of elder as follows (GKSA 1973:24-25 [author's translation]:

- An evangelist is a helper only in the office of the believer, whilst the elder is a special office in the congregation.

- An evangelist's work is a support service in subordination to the office of elder, whilst the office of elder is selfstanding and is not subordinate to that of the missionaries or sending church council.

- An evangelist's ministry is focused on the Gentiles (heathens), whilst the elder's duties are aimed at the church.

The training of evangelists, beginning in 1958, came to be viewed as a local task. This was in line with how this ministry was defined. The evangelist was not deemed to be an office of the church, rather an office of the believer. For that reason training was supposed to be a local task - not a task of the church in unity. Thus, missionaries were encouraged to train evangelists locally in order to lay the foundation for further training. The courses taught had to be approved by the mission deputies. This implied that training of evangelists had to be phased out. It was no longer part of the programme when the theological school moved to Hammanskraal.

However, the training of evangelist was not to go away that easily. As missionaries from the Netherlands came to South Africa, training of evangelists was resuscitated. The churches in the Netherlands not only encouraged and supported the establishment of Bible schools for local training - they also provided the financial support to those who served in the church as evangelists. As De Haan (2010) notes:

From the perspective of the Mission Board in Kampen, the evangelists had to be trained as leaders of independent local churches established truly on biblical principles. Most of the 
Kampen missionaries thought this to include an introduction in the Reformed dogmas. (p. 280)

Schools such as Iyani Bible School, Mareetsane (Sekolo sa Mojadi), ${ }^{11}$ Natal, Dimbaza Reformed Bible School, (and later Mukhanyo), were all started with the support of the Netherlands churches (see Brunsdon \& Van der Merwe 2013). The aim of these schools was to train and equip church workers, such as evangelists, elders and deacons, and also included various other church ministries.

In KwaZulu-Natal the formal training of evangelists started in 1962 with the arrival of Reverend M.R. van den Berg from the Netherlands to work alongside Reverend J. Vonkeman, who started working in the Richmond area in 1959. Van den Berg's missionary task was mainly focused on the training of evangelists (De Haan 2010:276). From 1977 there were two centres providing training: one at Richmond or eNkumane, and the other at Nqutu, which were also referred to as 'Sonqoba simunye' ['we will conquer as one']. ${ }^{12}$ The Bible schools in Natal produced a number of evangelists, some of whom subsequently became pastors and were ultimately recognised as ministers of the Word in the RCSA (see De Haan 2010:281-282):

- Stewart Zondi (1960-70).

- Abel Zitha (1962).

- Sonny Thamsanqa Mbadu (1962-1967, as pastor from 1967 to 1985, and as minister of the Word from 1985 to 2000)

- B.Q. Mtakwende (1962-1991, and as pastor from 1967 to 1972).

- M.P. Mlambo (1963-1964).

- P. Nkabinde (1964-1967, and as pastor from 1967 to 1973).

- L.S. Mbhense (1965-1966).

- S. Ndlovu (1965-1978, as pastor from 1978 to 1985, and as minister of the Word from 1985 to 1988).

- Mzizi (1966-1972).

- W. Molefe (1967-1977).

- E. Zuma (1967-1968).

- Mbambo (1968-1972).

- S.A. Vilakazi (1969-1970).

- M.C. Ngubane (1973-1977).

- M.M. Funeka (1971-1985, as minister of the Word from 1985 to 1993, and as pastor since 1994).

- J.B. Hadebe (1972-2006).

- W. Mkhize (1977).

- J.P. Sithole (1980-1991, and as minister of the Word since 1991).

- P. Sithole (1981-1983).

- R. Zuma (1981-1984).

- J. Mncube (1981-1984).

- A.B. Zaca (1982-1991).

- V.M.A. Mkhize (1983-1993).

11.For more on Sekolo sa Mojadi, see Brunsdon and Van der Merwe (2013)

12.The establishment of the two centres came out of a proposal made by two pastors of the GKSA, K.A.J. van Rensburg and D.C. Coetzee; the four missionaries from the NGK, A.A. Rietsema and J. Vonkeman, who were focused on the Richmond area; and R. Keesenberg and W.L. Kurpershoek, who were focused on the eNqutu area (De Haan 2010:288-289).
In the Natal school, the initial idea was that the training of evangelists should prepare them for their future work as ministers of the Word as decided by the Mission Board in Kampen (De Haan 2010:280). However, this was not to be until much later in the 1980s and 1990s, when the matter surfaced again. In the northern part of South Africa, Iyani Bible School (iyani meaning 'Go!') was started in 1966 under the leadership of Reverend J.A. van Rooy, who was called for this task in the Venda area by the Christelijke Gereformeerde Kerk Hoogeveen with the mission deputies of the Christelijke Gereformeerde Kirken Netherlands Synod (Buys 1998:254).

Sekolo sa Mojadi (school of the sower) was started in 1974 under the leadership of Reverend L. Huisman, who was sent as a missionary by the Gereformeerde Gemeenten in the Netherlands to the Distobotla District in the North-West Province (Brunsdon \& Van der Merwe 2013). Sekolo sa Mojadi was established at Batho-Batho Stad (Mareetsane) and so was also commonly known as Mareetsane.

Dimbaza Reformed Bible School (now known as Dumisani Theological Institute) was established in 1979 and has also been serving the reformed churches in the Eastern Cape since then. This institution was started through the cooperation of four churches: Free Church of Scotland, Free Church in Southern Africa, Gereformeerde Kerk East London and the Reformed Church Emonti. It focused on serving the amaXhosa people in the Eastern Cape. ${ }^{13}$

Thus, within the black RCSA there was a development of dual theological training under the influence of the GKSA and of the missionaries from the reformed churches in the Netherlands. On the one hand, there was centralised training of black ministers as initiated by the GKSA. The establishment of a theological school at Dube and later at Hammanskraal signalled development towards theological training that focused on the training of ministers of the Word. From the perspective of the GKSA, the initial and foundational missionary work in which evangelists were required had to be phased out as the training of ministers of the Word became more prominent. The phasing out of official training of evangelists was also occurring in other reformed churches in the region (see Cronje 1982):

- The Reformed Church in Africa (Indian): In the early stages of this church, evangelists were trained by missionaries. However, this church came to have a policy of no evangelists. Therefore, the evangelists serving in the church had to proceed with their studies and become ordained ministers.

- The Reformed Church in Zimbabwe: The training of evangelists, a work initialised by Reverend A.A. Louw Junior, started in 1925. The training of evangelists in the Reformed Church in Zimbabwe came to an end in 1953.

- The Reformed Church in Zambia: In the initial phase, evangelists came with missionaries from Malawi. Theological training in Zambia started in 1940, and the

13.This institution will be discussed subsequently. 
training of evangelists continued until 1950, when such training was stopped and the training of ministers started.

On the other hand, the Netherlands churches, which were continuing to send missionaries, continued with the missionary task of theological training of evangelists. Thus, whilst centralised training of ministers proceeded at HTS, local training of evangelists also continued in the various schools that were established by the Netherlands missionaries. Thus, the office of evangelists could not be completely phased out as envisioned by GKSA. This was due to the continued existence of duality in theological training: the training of ministers by the churches in unity with a centralised training and the local training of evangelists at various Bible schools. The continuity of the office of evangelist is owed to the missionaries of the Christelijke Gereformeerde Kerken in Nederland (CGKN) and the NGK, who have continued to propagate and support this office. The black RCSA, thus, continue to live with both ideological views with regard to theological training.

\section{Third phase (1961-1989): Training under the 1961 Theological Training Policy for the black Reformed Churches in South Africa}

\section{Framework: The 1961 Theological Training Policy}

In 1961 the white RCSA established a policy for the training of black ministers of the Word, which ushered in a new phase in theological training. The policy states (GKSA 1961):

With full acknowledgement and acceptance of the principle that every church (the Bantu peoples included) has the right to its own theological school, the synod has decided the following:

a. Initially, the full-time training of ministers and theologians of the reformed churches amongst non-whites will be done from an independent school.

b. The realisation of the ideal of multiple theological schools for the various ethnic groups will greatly depend on the development of mission and the independent development of the reformed churches in the different non-white population groups, with which the sending churches assist as far as possible, where necessary.

c. Theological training will be extended by one year so that it includes courses in the original biblical languages, which have to be taken in preparation. The application has to be referred to a senate of theological schools for non-whites.

d. The requirements for admission to the theological school from the beginning of 1962 must be elevated to a Senior Certificate, sustaining exceptions that the Curatorial may deem necessary.

e. Part-time training through correspondence must be rejected. (pp. 177-178, [author's own translation]):

From 1961 until 1989 this policy was the framework within which theological training was to be done in the black RCSA. This policy was drafted two years prior to the establishment of the three black national synods, which were established in 1963. This policy reflects the apartheid ideology of the time. The ideal situation that was projected in this policy was to have multiple theological schools for the different ethnic groups - thus reflecting the apartheid policy of 'separate development'.

The 1961 policy for theological training for the black RCSA was a policy of the white churches for training black ministers of the Word for the black churches; it was not a policy that was composed by the black RCSA. The 1961 Policy for Theological Training and the subsequent establishment of the black synods formalised the racialised identities within the RCSA that resulted in vested racial and theological interests, which would later prove hard to overcome.

Given the paternalistic relationship between the white and black RCSA, theological training during this phase continued under control of white RCSA, but afterwards the black synods started to have deputies for theology, and eventually representation in a bree kuratorium [broader board of curators].

\section{Hammanskraal Theological School in the context of four national synods: 'Ons skool vir hulle'}

HTS was, as a matter of principle, a school of the GKSA for the training of ministers of the Word for the three black national synods: RCSASKNS, RCSAMNS and RCSASNS. There was a saying 'ons skool vir hulle' ['our school for them'] (GKSA 1964:264). This had a number of implications:

1. The ownership of the HTS was in the hands of the white churches. This made it clear to all the black synods that the school was not theirs, but for them. This meant that they did not have much say on how the school was run. It was not their school. The black synods were informed of how the school was running by the delegates who represented the school at their synods.

2. Initially no black people were appointed to be part of the board of curators at HTS. The black synods did not have deputies for theological training. In 1967, the white synod decided that the other national synods might nominate deputies who liaise with the board of governors in some cases and with whom the curators' board liaise with (GKSA 1967:270-271; 1973:60-61). It was only following this decision of the GKSA that the black RCSA started having deputies of theology (RCSASNS 1968:5). It is clear from this that the aim was not for the other synods to have representation on the board of governors and curators. Rather, their role was limited to that of liaising with the board and the curators. The deputies were not regarded as those who would contribute towards the running of the school. The role that the black churches were expected to play was simply a supportive one in the form of offering advice - not as insiders, but as outsiders. The concept of a 'breë kuratorium' ['the broader board of curators'] was only introduced in the late 1980s in order to accommodate representatives from the black RCSA in the board of curators (Van Wyk 1988:29).

3. The black churches were called upon to support the school as it trained their people, although it did not belong to them. The support they had to offer was prayer, students 
and financial contributions towards the running of the school. The black churches themselves were financially supported by the white churches and could hardly financially support the theological school.

4. There was no involvement of black people in the training of ministers at HTS. Not a single black professor was appointed to be part of HTS before its closure in 1994. Mandiwana (1983) writes regarding this unfortunate state:

The policy of our country is that each nation has to develop separately. In my opinion, the HTS fulfils such a separate development in the field of theology. The black churches have been waiting to have their own black professor one day. Hammanskraal is the only instrument of hope for that dream to be realised. (p. 54)

5. If the black national synods wanted to have their own theological schools, they were free to go ahead and do so. HTS was not their school, and therefore throughout the 42 years of formal training there was no intention of grooming black leadership to take over the school and develop it further. The black people were simply supposed to go through the school as students and were not supposed to dream about being academics.

HTS was successful in training a large number of students in its 42 years of existence. However, its closure in 1994 signified its failure to groom black theologians who would carry on the task of training their own. This was the greatest failure of HTS.

During this period, theological training of ministers was for the most part centralised at HTS. However, in the 1980s there was a sense amongst the Netherlands missionaries that their Bible schools should be allowed to broaden their scope to include the training of ministers of the Word. The need for Bible schools in Natal to include training of ministers of the Word resurfaced in the 1983 synod sitting of the RCSAMNS, when the Itheku Classis, which was the classis of churches in the KwaZulu-Natal, brought to the synod the need to start theological training in the Natal area (RCSAMNS 1983:6162). Following a meeting between the RCSAMNS deputies appointed to attend the issue of theological training in Natal and the representative of Itheku Classis and the missionaries of the NGK (A.H. Reitsema, B. Wielenga, J. Vonkeman and W.L. Kurpershoek) in 1986, the deputies of RCSAMNS were of the opinion that the matter be put on hold. The report of deputies of RCSAMNS (1987) states:

It was again clear that there are [sic] too wide a difference about what missionaries envisaged and what the deputies of the synod think about. At the meeting it was clear that the missionaries [...] desire that the training that they are giving to their 'helpers' be recognized as ministerial training, and that they thus simply be given the church right to continue with it. The deputies on the other hand felt strongly for a standard of training not inferior to that at Hammanskraal; and also not a training that is only in the name of the churches while it is done as part of mission work. (p. 105)

Thus, towards the end of the 1980s, the school initiated by the Netherlands missionaries, the Natal schools and Sekolo sa Mojadi of Mareetsane started to include the training of ministers in their programmes, so that, by the end of this period, training of ministers was no longer solely done at HTS.

\section{The lack of political consciousness from black ministers and students trained at HTS}

Denis (2010:163) notes that 'during the first three quarters of the twentieth century, theological education of South Africa experienced both centralisation and segregation'. In the mainline churches, black candidates for ministry of the Word were trained in the following seminaries (see Denis 2010:163):

- The Federal Theological Seminary in Alice (Anglican, Methodist, Presbyterian and Congregational churches).

- The Lutheran Theological College in Umphumulo (Lutheran churches).

- St. Peter's Seminary in Hammanskraal (Roman Catholic Church).

- Stofberg (Dutch Reformed Church).

- HTS in Hammanskraal (Reformed Church in South Africa/Gereformeerde Kerk in Suid-Afrika).

In the RCSA, when the three black synods were constituted in 1963, the following were ordained ministers in accordance with the synods and churches they were serving in at the time (see GKSA 1978):

- Synod Soutpansberg had three ministers: M.S. Mugeri (Soutpansberg), S.P.M. Moshapo (De Hoop) and B.J. Maselesele (Hosiyata).

- Synod Midland had 25 ministers: N. Bohloko (Thabong), G. Mokoena (Meadowlands), A. Ntela (Dobsonville), P. Silas (Strubenvale), S.R. Madia (Natalspruit), J. Matsoso (Waterkloof), E. Matlakala (Stilfontein), C. Khoza (Vanderbijlpark), S. Seadira (Potchefstroom), A. Dlamini (Kwa-Mashu), D.V. Mahole (Lichtenburg), G. Mthiyane (Thembeni/Durban), Modiba (Daveyton), E. Tlali (Odendaalsrus), J. Lebitsa (Atteridgeville), J. Moseki (Mafikeng), E. Chaka (Sharpeville), J. Mohloki (Sannieshof), S. More (Jabavu, Johannesburg), M. Mashinini (Moroka), F. Motau (Hammanskraal), J. Molehabangwe (Uitschot), K. Ncoco (Nelspruit) and T. Ramatsui (Bronkhorstspruit).

- Synod Suidland had four ministers: A.G. de Leeuw (Venterstad), S. Maas (Benoni-South), A. Lakay (GrassyPark), and J.W. Matthysen (Newclare).

With such a pool of ministers already in service in the 1960s, it is not unreasonable to expect these churches to have made their presence felt by speaking against the apartheid ideology.

During the 1960s and the 1970s there was development of political consciousness amongst university students and seminaries (Denis 2010). When the University Christian Movement (UCM) was established in 1967, as Denis (2010:165) notes, there were nine seminaries in the directory 
of that multi-racial student organisation: Federal Theological Seminary, Livingstone House, St. Peter's, St. Scholasticate, St. Nicholas Priory, St. Paul Theological College, St. Bede's College, Lutheran Theological College and Moravian Theological Seminary. Not included in the list were St. John Vianney Seminary, Dutch Reformed seminaries, Baptist seminaries, the Bible schools and Bible colleges of the evangelical churches or the GKSA theological schools. In 1968 the South African Students' Organisation (SASO) was started as a black student organisation - it was associated with Steve Biko and the black consciousness movement in South Africa. During this time the development of black theology alongside the black consciousness movement can also be seen. In the early stages of black consciousness, the most ardent proponents of this movement were seminary students, who placed a particular emphasis on black theology (Denis 2010:163; Gerhart 1999:294).

Black theology, however, was not well-received by the apartheid regime and by the white reformed churches, particularly the Dutch Reformed Church (DRC) or NGK, the Gereformeerde Kerk in Suid-Afrika (GKSA), and the Nederduitse Hervormde Kerk, all of which supported the regime and provided the theological justification for apartheid (see Giliomee 2003:482-486; Lategan 1999:132). The DRC attracted the greatest attention, as it openly provided a 'biblical' rationale to justify apartheid (see Landman 1968; Dutch Reformed Church 1976a; 1976b). During this phase, to align oneself with black theology was an act of defiance - to take a stand against the apartheid regime and the churches that provided the justification for the apartheid ideology. The alignment with black theology also invited the harsh reality of victimisation and persecution. In 1972, the book Essays on Black Theology was banned by the apartheid regime just a few weeks after its release. Some of the leading figures of the black theology projects, such as Sabelo Ntwasa, Basil Moore and Madibeng Mokolitoa, were also banned (Mothlabi 2005). Black theology was a theology of liberation born out of the lived experience of oppression.

In the black RCSA, there was deafening silence, especially in the 1960s and the 1970s as these churches did not make their voices heard against apartheid, nor did seminary students at HTS participate in the black consciousness movement. There are several factors that contributed to this deafening silence of the black RCSA in the 1960s and 1970s.

Firstly, the theological training that ministers of the black RCSA received failed miserably to make them conscious of the life-denying realities facing them and their congregations, their communities and their country. The theological education they received was out of touch with the sociopolitical realities in which they moved and lived. This reflects the oppression of the mind within this church circle. As Biko (1987:92) noted: '[T]he most potent weapon in the hands of the oppressor is the mind of the oppressed.' This, however, does not make the black RCSA innocent, but rather it is guilty for its complacency with oppression and injustice. Boesak
(1976:3) rightly warned of the 'pseudo-innocence' in which 'when people face issues too horrendous to contemplate, they close their eyes to the reality and make a virtue out of powerlessness, weakness and helplessness'. The silence and neutrality of the ministers in the black RCSA was a betrayal of the poor, oppressed and suffering to whom they ministered, and ultimately a disobedience to God. The failure to heed the call of the poor, oppressed, and suffering was failure to heed the call of God. As Boesak (2014) notes:

Calvin, when speaking of the cries of the poor and the oppressed, goes on to say that when they, like the psalmist, cry 'How long?' it is then as though God hear[s] himself, when he hears the cries and groaning of those who cannot bear injustice. (pp. 32-33)

Secondly, the lack of black people as part of the teaching staff theologically enclosed the students. In the 1960s and 1970s African theology and black theology were gaining ground in South Africa and the African continent, but students were not exposed to such ways of theologising. In the GKSA, black theology was also cast in a negative light. In an article published in Jubileum Jaarblad of the Hammanskraal Teologiese Skool van die Gereformeerde Kerk in Suid-Afrika, Stavast (1973) writes regarding black theology: 'Die Swart Teologie is ' $n$ aardse teologie! Hulle verwerp elke opvatting van God wat sou wil inhou dat die wil van God ook lyding vir swart mense kan inhou' ['Black theology is a worldly theology! They reject every notion of God yet claim to present the will of God for the suffering Black people.'] (p. 14, author's own translation). Further Stavast (1973:15) writes:

\footnotetext{
Die swart teologie reduseer God en Christus egter tot instrumente van 'n ekonomiese en politiese revolusie en die mens word gereduseer tot 'n materialistiese Marxistiese wese wat geen ander doel en oogmerk ken as die stof van die aarde nie. Dié is vir hulle die koninkryk van God. ['Black theology reduces God and Christ to instruments of economic and political revolution and the people are reduced to a materialist Marxist being who have no other purpose and are objects as dust of the earth. This is for them the kingdom of God'] (p. 15, author's own translation)
}

No wonder there was a deafening silence from the HTS students and black ministers trained at this seminary. To engage in black theology was portrayed as engagement in a worldly theology. This served to enclose HTS students and the black ministers from theologising in a manner that would challenge the status quo, to start relating their lived experience of suffering, racism, oppression, segregation and many other life-denying realities with the Word of God. As De Gruchy (2005:155) points out, black theology 'had both a negative critical thrust and a positive, constructive dimension. It was a theology of protest against apartheid, but it was also one of liberating reconstruction'.

Thirdly, the black synods were financially dependent upon the white synod - it was the white churches that paid the salaries of the black ministers. None of the ministers during this phase depended on their local churches for financial sustenance. The Tshivenda proverb comes to mind: Mmbwa a i lumi tshanda tshi ineaho zwilizwa [A dog does not bite the 
hand that feeds it]. Baloyi (2010) reflecting on what he calls the 'effect of sustentasie on Black theology amongst Reformed ministers and theologians' writes:

The church belongs to those with money, while Black ministers are just obliging and following the regulations of the hands that feed'. Black church members even know that their Black ministers have no say, but that the White man who gives them second-hand clothing and pays their school fees is the one with the final say. A Black critical mind is not encouraged. (p. 425)

If indeed the black critical mind continued to be discouraged through the purse in the post-apartheid era, as Baloyi claims, how much more, during the apartheid era in which the black RCSA were for the most part under the mercy of the white churches. For Mashau (2003:125) and Baloyi (2010:425), it is the dependency of the black ministers on the white churches that has been the chief obstacle for them engaging in black theology.

The black ministers of the RCSA did not provide an alternative way of theologising against apartheid theology and the colonial-apartheid regime, nor did they provide an alternative to black theology and/or liberation theology in order to address the challenges that faced the indigenous people. It was only in the late 1970s and in the 1980s, when the black RCSA started participating in the Reformed Ecumenical Synod (RES), that the black RCSA synods started speaking out against apartheid in South Africa. The Metsi-AMatala Report on the issue of race relations in South Africa in the RCSAMNS (1983) was occasioned by a questionnaire sent by RES to the participating churches to respond on issues of race relations in order to guide the RES. However much discomfort the report might have caused in the GKSA, it still falls short of declaring the apartheid system a heresy.

It is no surprise that the delegates of the Orthodox Presbyterian Church (OPC), following a meeting that they had with the deputies of the four synods of the RCSA, would write this in their report (see Report of the OPC delegation about South Africa in the Report of Deputies for Ecumenical Matters, RCSAMNS 1987):

(6) The subcommittee was struck to learn that in the perception of almost all the representatives of the nonWhite churches, most nonWhites believe that the State President Botha is a man of integrity, that the intention of the government to bring about change is sincere, and that while much more needs to be changed as soon as possible, it is moving about as fast as can be expected.

(7) On the issue of disinvestment, which has received so much attention world-wide, apparently most nonWhites are strongly opposed to it. It is bringing about increased economic hardship for nonWhites. One nonWhite representative even referred to it as a form of violence against nonWhites. Apparently, too, much of the agenda of figures like Bishop Desmond Tutu and the Reverend Alan Boesak, a minister in the (coloured) DR Mission Church, who have been given visibility by the world press, is not supported by the large majority of nonWhites in South Africa. (pp. 111-117)
The OPC report sadly reflects the deep oppression of the mind of the black ministers within the RCSA. However, such a situation could not be sustained, as the bells of political liberation were continuing to ring louder and louder, culminating in the release of Nelson Mandela from prison in February 1990. Political liberation, however, did not necessarily translate into church liberation, as the RCSA circle remained segregated in accordance to the apartheid synod structures of 1963 for the next almost 20 years. To use VillaVicencio's (1986) phrase, the RCSA structurally remained 'trapped in apartheid' as the country was in transition from apartheid to non-racial democracy.

Vosloo (2013), reflecting on the legacy of the RCSA in general, notes that this legacy:

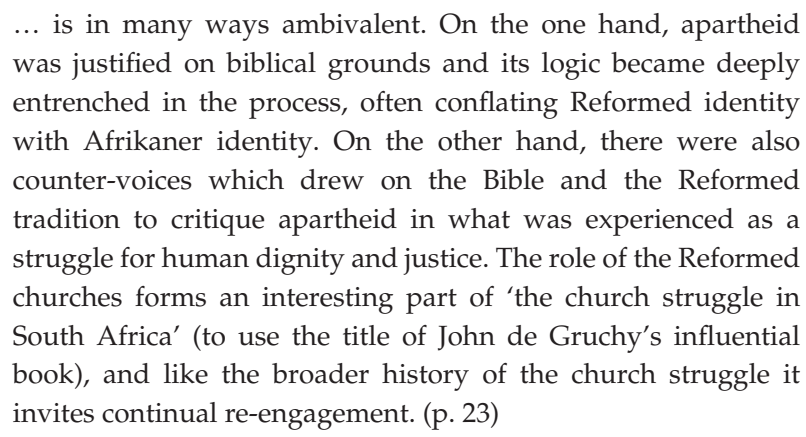

In the RCSA, the church's struggle manifested itself amongst other things in theological training. The racialised and segregated training, the protracted dependency of the black RCSA on the white churches for theological training, the failure to conscientise the black students and ministers of the life-denying realities facing the black populace, and the failure to groom black academics are all aspects of the struggle of human dignity and justice.

\section{Fourth phase (1990-Current): Theological training in the context of a new South Africa}

The political changes in South Africa in the late 1980s and the early 1990s - the undercover contacts, the release of Mandela, the unbanning of the ANC and other political parties, the National Peace Accord in 1991, CODESA in 1992, the Transitional Executive Council and associated bodies in 1993-1994, and the first democratic election in 1994 - all reflect a significant paradigm shift in the South African context. This paradigm shift, on the one hand, was a restorative process in which the previously suppressed were regaining their self-confidence to do things on their own and, on the other hand, the need for desegregation. The paradigm shift from apartheid to democracy was indeed a great achievement, however, the new era also has its disappointments. The economic and spiritual conundrums of South Africa are epitomised, on the one hand, the Marikana tragedy, in which 34 miners were killed in the struggle for better living wages, and, on the other hand, the tragedy of the collapse of a building of the Synagogue of the 
Church of All Nations in Lagos, Nigeria, in which 84 of the over 300 South Africans who had gone there for spiritual nourishment lost their lives. It is this broader context in mind that we continue to reflect on theological training in black RCSA since 1991 - a situation marked by both achievements and disappointments.

Towards the end of the 1980s, with the winds of political and economic change blowing, the GKSA began to reflect on the future of HTS (GKSA 1978):

Die Sinode doen ondersoek of dit nog wenslik is om voort te gaan met die Hammanskraalse Teologiese Skool as 'n selfstandige skool in die lig van die veranderde realiteit en finansiële oorwegings. [The Synod [GKSA] enquires whether it is worthwhile to continue with Hammanskraal Theological School as an independent institution in light of the changing realities and financial considerations.] (p. 772, [author's own translation])

The motivation for this was as follows (GKSA 1978):

In die lig van die totstandkoming van die Algemene Sinode en die lig van opheffing van die wetlike beperkinge oor akademiese opleiding aan blanke universiteite en die eknomiese realiteite, word dit noodsaaklik dat die Sinode opnuut besin oor die rigting waarheen met die Hammanskraalse Teologiese Skool beweeg moet word. [In light of the coming General Synod and the legal restrictions on academic training in White universities and economic reality, it is imperative for the Synod to reflect on the direction that Hammanskraal Theological School should take.] (p. 773, [author's own translation])

In 1988 the broad curators' board of HTS sent a memorandum to the alumni, requesting their input on the future of HTS. In 1989 the Board sent letters to the black synods requesting their input regard the future of HTS. The black synods responded differently to this enquiry of the GKSA regarding their school for the training of black ministers. However, even though the prospects of HTS were critical for the black synods, other factors entered that would shape the landscape of theological training in the black RCSA. In the late 1980s and early 1990s, there were some developments and changes that were being effected at HTS. Van Rooy (1990:288), reflecting on theological training in Africa, points to the following developments and changes at Hammanskraal.

Firstly, HTS started drawing students from elsewhere in Africa - from Mozambique, Zaire, Malawi and Zimbabwe. It should be noted, however, that this occurred while students from Korea and elsewhere were being received at PU for $\mathrm{CHE}$; this points to the segregation of black Africa at the time.

Secondly, English was introduced as the language of instruction instead of Afrikaans. Van Rooy (1990) writes:

Nog 'n belangrike verandering is dat die opleiding op Hammanskraal na Engels as medium van onderrig moet oorskakel. Die doel van die Hammanskraal Teologiese Skool is nie om die Afrikaanse taal en kultuur te bevorder nie, maar om met die mense van Afrika te kommunikeer en die Gereformeerde teologie vir hulle as erfenis na te laat. Hiervoor is daar net een aangewese medium buiten die Bantoetaal, in dit is Engels. (Daar word aangeneem dat daar nog nie die middele is om kursusse ook in Portugees en Frans aan te bied nie, laat staan nog Swahili en Arabies!). [Another important change is that theological training at Hammanskraal is switching to the use of English as the medium of instruction. The purpose of Hammanskraal Theological School is not to foster the Afrikaans language and culture, but to communicate with the African people and to leave them with the Reformed heritage. Outside of the Bantu languages, there is only one designated medium of instruction, that is, English (This assuming that there are no theological resources in Portuguese and French, let alone Swahili and Arabic!).] (p. 288, [author's own translation])

Thirdly, practical training for the full-time students was introduced. Van Rooy (1990) again writes:

Een verdere wysiging in die bestaande patroon van ons voltydse opleiding sou wees dat daar meer aandag aan praktiese opleiding gegee sal moet word. In hierdie opsig behoort die voorstel wat ds. Chris Coetzee by die opfrissingskursus gedurende Januarie 1990 te Hammanskraal gemaak het, van harte ondersteun word. Die voorstel behels dat aan elke professor 'n woongebied toegewys moet word wat hy saam met ' $n$ aantal student moet bearbei om hulle aspekte van die opleiding prakties te leer toepas, sendingwerk inkluis. [Another amendment to the existing full-time programme would be increased attention given to practical training. In this regard, the proposal made by Rev. Chris Coetzee during the refresher course in January 1990 at Hammanskraal, should be supported fully. The proposal involves every professor being allocated a residence where he and assigned students can do their practical training in order to put the theory into practice.] (p. 288, [author's own translation])

Some of these changes, which were being effected during this time, highlight the disconnection between HTS and the black-African context that existed between HTS and the black RCSA for many years. More pertinent for us at this point is to note that the GKSA, after almost 40 years, had started contemplating the closure of HTS. However, the GKSA wanted the input of the black RCSA synods on the matter.

\section{RCSASKNS on the future of HTS}

The RCSASKNS in its 1990 synod, which was the last meeting of this synod, decided the following with regard to the future of HTS in response to the letter from the broad curator's board of HTS (as quoted in GKSA 1991):

Die Sinode oordeel dat die pogings wat aangewend word om die HTS die verantwoordelikheid van al die kerke te maak, verwelkom word. Die Sinode werk saam met die Kommissie van die HTS om 'n sinvolle oplossing te vind sodat die HTS ' $n$ beter beeld in al die kerke sal hê. Dus steun die Sinode die standpunt dat die HTS moet voortbestaan, maar dat al die kerke volle verantwoordelikheid sal aanvaar. [The Synod considers it necessary that the efforts made for HTS to become the responsibility of all churches are welcomed. The Synod is working with the commission of the HTS to find a meaningful solution for HTS so that it will have a better image in the eyes of all the churches. Therefore, the Synod supports the view that HTS should continue, but with all of the churches taking responsibility.] (p. 757, [author's own translation]) 
The motivation offered for the continuity of HTS highlighted the following (as quoted in GKSA 1991):

1. HTS was regarded as presenting an opportunity for those who did not qualify to study at TSP.

2. There were still students from the RCSASKNS for whom it would be difficult to meet the requirements of TSP.

3. HTS was regarded as able to deal with a variety of needs and challenges facing students.

4. RCSASKNS indicated its satisfaction with the standard and curriculum of training at HTS (p. 757).

The RCSASKNS motivations have to be viewed in light of this synod's earlier proposal in 1982 for its prospective students to be allowed to study at TSP, and in some cases do their studies at HTS (RCSASKNS 1982:85). However, at the time, the RCSASKNS also noted there was decision that each race should have its own theological school (RCSASKNS 1985:301, 302). The situation of the RCSASKNS in the 1990 sitting was about to change. This synod was going to disband and join the GKSA church structures. For the RCSASKNS, continuity of HTS would serve these churches by accommodating those students who would not be able to meet the requirements at TSP. This signalled a move towards unification between the RCSASKNS and GKSA - not simply the church structures, but also in theological training. For the RCSASKNS, the main centre of training was no longer going to be HTS, but TSP. Whilst the mixed race churches now had the opportunity to receive their training at TSP, this option was not open to all the black synods. The opportunity for other black synods to have their students trained at TSP would only be realised once the country had fully transitioned from the apartheid government to a democratic government following the 1994 elections.

\section{RCSAMNS on the future of HTS and the multiple theological training institutions}

In its 1989 sitting, the RCSAMNS responded to the letter of the broad curators' board and highlighted the following two key issues:

1. The situation at HTS in which the black churches have no say in the running of the school, nor in the appointments of professors, and their supervision was unsatisfactory and undesirable.

2. The synod considered it necessary for HTS to continue to exist, though with the involvement of all churches (see RCSAMNS 1989:Bylae BB).

The RCSAMNS gave the following motivation for the continuity of HTS:

1. The churches of RCSAMNS have a historical tie and relationship with HTS.

2. HTS was regarded as a good foundation that had been laid for the churches in the RCSAMNS.

3. The RCSAMNS regarded HTS as meeting the requirements set by the synod for theological training (see RCSAMNS 1989: Bylae BB).
However, the situation of theological training in the RCSAMNS required a solution more complex than simply resolving the issue of continuity or discontinuity of HTS. In the black RCSA, unlike in the white circle in which there was only one theological training institution, there had been multiple theological institutions beginning since the 1960s. However, prior to 1990 only HTS had the mandate of training ministers, whereas the other theological training centres were focused on training evangelists and equipping other ministries of the churches. From 1990 onwards this situation changed. The black synods, RCSAMNS and RCSASNS, responded differently to the winds of change in the broader South African context.

Within the RCSAMNS, the other theological training centres, such as Natal and Sekolo sa Mojadi, were given the right to broaden their scope to include the training of ministers. As already noted, theological training in Natal had two centres, one at Richmond and the other at Nqutu. Mukhanyo Theological College's genesis went back to the work of Bob Rebel, a missionary from the Netherlands who had served in the Venda area prior to moving to the KwaNdebele area to continue his missionary task. He responded to a request from the leaders of the African Independent Churches (AIC) by offering informal training for the AIC's church leaders. Under the leadership of Dr Flip Buys, Mukhanyo Theological College's scope was broadened through the years, and it consequently also became involved in the training of ministers of the RCSAMNS, following the request of Classis Tshwane and the approval of the RCSAMNS. ${ }^{14}$ Thus, from 1990, the RCSAMNS ministers of this black synod were being trained at five different institutions: HTS, Natal (the Richmond centre and the eNkumase centre), Sekolo sa Mojadi and Mukhanyo Theological College. In the 2004 RCSAMNS synod, Classis Emonti raised the issue of the recognition of Dumisani Training College and Bible School (now known as Dumisani Theological Institute) in the Eastern Cape, ${ }^{15}$ but the RCSAMNS responded that this training centre was unknown to it (RCSAMNS 2004:19). Despite this response, the Reformed Church Emonti, along with the white Gereformeerde Kerk East London, continues to recognise this theological training centre, and these two churches are part of the four churches involved in the running of this school, which includes the Free Church of Scotland and the Free Church in Southern Africa.

These theological training institutions functioned independently and did not have a common curriculum. This brought with it the challenge of regarding the training at the other centres, Sekolo sa Mojadi and the Natal centres, as inferior to the training received at HTS (Brunsdon \& Van der Merwe 2013; Baloyi 2010:430). In addition, some of the lecturers in the other theological training institutions were

14. Between 1994 and 2004, Mukhanyo Theological College had trained eight pastors who were serving in the churches, many of whom were concentrated in the area of KwaNdebele.

15.This institution as already noted initially known as Dimbaza Reformed Bible School. In the RCSAMNS, the issue of Dumisani Training College and Bible School only started surfacing at the synod level in 2004 . From 1997, this school started offering degrees in association with Potchefstroom University for Christian Higher Education, now North-West University (Potchefstroom Campus) (see http://www. Education, now North-West University (Potchefstroom Campus) (see http://www.
reocities.com/Athens/aegean/8696/). 
regarded as underqualified (RCSAMNS 2004:8). In 1991 the RCSAMNS' deputies of theological training reflected on the situation of multiple theological centers for the training of ministers as follows (RCSAMNS 1991):

Die ideal is steeds een opleiding vir alle predikante van die Gereformeerde Kerke. Dit beteken nie noodwendig net een plek vir teologiese opleiding nie. Dit beteken egter dat alle opleiding onder toesig staan van dieselfde kuratorium en dat oorleg gepleeg moet word tussen die verskillende opleidingsentra. Die dosente aan die HTS moet die werk van ander sentra modereer en daar moet oorleg gepleeg word oor die kurrikulum. [The ideal is still to have common training for all ministers of the Reformed churches. This does not necessarily imply one centre of theological training. It implies, however, that all theological training that is done by the different centres has to be supervised and coordinated by the same board of curators. The lecturers of HTS must have the responsibility of moderating the work and consult the other centres with regard to their curriculum. (pp. 31-36, [author's own translation])

The ideal of a centralised or one theological training at this point did not imply common theological training between blacks and white students. Rather, it was an issue of a common curriculum in the various theological training centres serving the RCSAMNS. The different theological centres, even though they were serving the RCSAMNS, were not under control of the RCSAMNS. There were different stakeholders involved at different levels in these theological centres. The missionaries serving in the different schools had to fulfil the missionary activity in line with their respective sending reformed churches from the Netherlands that funded their work and the theological centres (see also Wielenga 2004; RCSAMNS 1994:Report of the Deputies of Theological Training). The RCSAMNS involvement in the different theological training centres was limited to being on the board of curators. Thus, even though the RCSAMNS endorsed and accepted candidates trained in the multiple theological schools started by the Netherlands missionaries and also HTS, which was started by the GKSA, it did not have any sense of ownership in any of these schools. The relationship between the Netherlands mission and the RCSAMNS as well as between the GKSA and the RCSAMNS, was, at best, paternalistic with regard to theological training.

The multiple theological centres of training and the lack of substantial involvement in the training of their own ministers reflect the complacency within the RCSAMNS. This was to a large extent due to the financial dependency of the churches within this synod on the white churches, on the GKSA and also on the Reformed churches from the Netherlands that were involved in mission. Furthermore, the RCSAMNS failed to have regular sittings during the critical period in the history of the country - only sitting in 1991, 1994, 1997 and seven years later in 2004. The failure of this synod to sit regularly implied that it could not effectively discharge its duties, which in turn implied that the various classis could take critical decisions without seeking the endorsement or approval of the synod.

The RCSAMNS was, so to speak, institutionally rich, notwithstanding that it did not have the ownership of any of these institutions. This institutionally rich synod's involvement in the training was limited to playing the role of curators without playing a direct role in the teaching and learning of the students. The involvement of black lecturers in teaching in these institutions was at best minimal. This in turn implied a continued failure to develop black academics from within the black RCSAMNS.

\section{RCSASNS on the future of HTS and a black own theological institution: Heidelberg Theological Seminary}

The RCSASNS pursued a different trajectory with regard to theological training. On 05 January 1991, the RCSASNS officially opened its own theological school: Heidelberg TheologicalSeminary (from now on referred to as Heidelberg). The official launch of Heidelberg was a culmination of the process that started in 1988. In the RCSASNS, the enquiries regarding the future prospects of HTS were probably viewed as the beginning of the process that would eventually lead to the closure of this seminary, thereby instigating the move to establish another seminary. The RCSAMNS (1989) synod in 1989 indicated that:

Die sinode kan nie besluit om iets te sluit of nie te sluit nie, te koop of nie te verkoop nie. Die HTS is nie 'n skool van hierdie sinode nie en bowendien word dit beheer deur die sinode GKSA (Potchefstroom). [This synod cannot decide whether something should be closed or not, or whether to sell or not. HTS is not a school of this synod and, moreover, it is controlled by the synod GKSA (Potchefstroom).] (p. 79, [author's own translation])

It comes as no surprise therefore that in 1989 the De Hoop Reformed Church and Niani Reformed Church both sent letters to the RCSASNS of that year requesting that the synod start the process of establishing its own theological seminary (RCSASNS 1989:20, 67-68, 69-70). The following were offered as motivating factors:

- Contextual 'Reformed' theology is needed to enrich the theological landscape within the African context.

- Churches need to be enriched and developed theologically. In order to achieve this, it was deemed necessary to establish a school that would be under the control of the synod.

- The apartheid system and racial discrimination of the time necessitated the need for the black churches to have their own theological seminary. The black churches were not directly involved in HTS and TSP, and regarded them as schools of the white churches, GKSA. HTS was a part of the white churches' missionary activity. Black churchmen were limited to being curators, not involved directly in the training of students. The churches did not have ownership of these schools and did not have a say on the appointments of professors in them.

- Missions-oriented churches needed to be fostered. This implied that black churches needed to move from being viewed simply as targets of missionary activities to becoming churches also involved in mission. This could be fostered through the training of missionaries. 
The RCSASNS' establishment of a theological school implied that these churches would now play an active role in theological training. There was nothing stopping this, and it was what the GKSA had envisioned in the beginning anyway: multiple theological schools. However, this time it was different. Heidelberg was not a white-owned school for black people; rather a theological school out of the black RCSA's own initiative.

The RCSASNS sought the support for its intent to start a seminary from the other black synods, but it was unable to successfully garner their support. RCSASKNS did not discuss the matter in its synod sitting of 1989, and their 1990 synod turned out to be the final synod as they decided to disband to join the structures of the GKSA (see RCSASNS 1990:64-65). The RCSAMNS, on the other hand, decided not to work with RCSASNS in this regard. Instead, this synod affirmed its ties with the white-owned HTS (RCSAMNS 1989:48-50). This implied that the RCSASNS did not receive the support of the other black synods.

\section{Phasing out of HTS and Heidelberg}

In 1994 South Africa successfully held its first democratic election. With the winds of change blowing, negotiations started between GKSA and black RCSA to phase out HTS and Heidelberg and have the students study at the previously whites-only institution, the TSP at Potchefstroomse Universiteit vir Christelike Hoër Onderwys. In 1989, the majority of the black synods were advocating for the continued existence of HTS. However, five years later the closure of HTS was on the table. This time there was no resistance to the idea of closing down HTS. It is also not surprising that the RCSASNS decided to shut down Heidelberg, considering the newly found freedom and the desire to gain access into the previously whites-only institution.

In 1995 the RCSA moved towards unity of black and white churches with regard to theological training. The phasing out of HTS and also of Heidelberg in 1994 meant that, for the first time in the history of the RCSA, black and white people would come to receive their training in one and the same institution: TSP.

The unification of the seminaries also had positive payoffs:

1. The training of black students at TSP opened up an opportunity for them to be trained at a renowned institution in South Africa: Potchefstroom University for Christian Higher Education (now North-West University).

2. The students later came out of this institution with masters degrees, thereby placed in a good position to further their studies.

3. It is also worthy to note that, since 1995, some of those students who went on to pursue doctorates are now academics and professors at TSP, North-West University and other institutions. What HTS and the other theological institution initiated by the missionaries failed to achieve in more than 40 years of their existence has been achieved in less than 20 years.

4. Since 1995 a number of black professors have been appointed at TSP: Thinandavha D. Mashau, Letšosa Rantoa, Lekgetho Moretsi, Risimati Hobywane and Aaron Muswubi.

5. With the closure of Heidelberg, Dr T.C. Rabali went on to work at Vaal Campus of the Potchefstroom University for Christian Higher Education, and also started assisting at the Tshiawelo Reformed Church in Soweto. This move helped to facilitate the beginning of urban mission by the black RCSA in the Gauteng area (see Mutavhatsindi \& Meiring 2014).

A number of negatives also came with this move to close Heidelberg:

1. The closure of Heidelberg distanced the seminary from the churches that started it.

2. TSP was a school for the white churches, and they were only willing to accommodate two representatives from each of the black churches on the curators' board. This was a school of which the black churches could not claim ownership. TSP, as the white churches claimed at the 1988 General Synod, was their institution, and they were not willing to let the General Synod decide on the affairs of their institution. This had not changed in 1994, when there were still three synods, and so TSP was still an institution of the GKSA.

3. At TSP, just as at HTS, the black RCSA were left to hold the short end of the stick as there were no immediate appointments of black professors. Dr T.C. Rabali, who was the principal of Heidelberg when it was shut down in 1994, went on to take a position at the Vaal Campus of PU for CHE.

4. The phasing out of Heidelberg resulted in many of the black ministers who had been involved in lecturing now becoming less involved in academic and scholarly work.

It is important to note that the move to allow other theological institutions to include the training of pastors in their scope, whilst at the same time negotiating for the closure of Heidelberg and HTS, undermined the unity in theological training that was being sought. Thus, whilst at the broader level the GKSA and the black RCSA were ideologically and practically moving towards unification with regard to theological training, the missionaries from the Netherlands were continuing with the decentralisation of theological training. For the Netherlands missionaries, the ideal situation was to have multiple theological seminaries servicing the black churches (Vonkeman 1983). The theological institutions established by the Netherlands missionaries continued to function alongside the now central training of all the synods of the RCSA. Baloyi (2010:430) attributes this conundrum to the 'masterminding' attitude reflected by those who funded these theological institutions. This conundrum, however, cannot be solely attributed to the financial aspect. There were two things at the core of this. Firstly, the attempt to achieve 
a centralised theological training was not grounded on the proper structural unity of the church. The synods were still racially divided and structurally independent of each other. In addition, the General Synod of the RCSA, which was the broadest level at which centralisation of theological education would have been properly addressed, had become nonfunctional. ${ }^{16}$ Secondly, the Netherlands missionaries who facilitated the start of other theological schools tended to downplay the significant baby step attempts that were being made to overcome the racial division within this RCSA. Even though the theological schools started by the Netherlands missionaries were not all solely aimed at the training of those within the RCSA, this did not help the situation, which was already volatile. The broadening of the scope of other theological institutions implied that the envisioned ideal of centralised theological training for all candidates for the ministry in RCSA would not be achieved, especially within the black RCSA.

\section{The re-establishment of Heidelberg Theological Seminary}

The ideal of centralised theological training of all ministers of the RCSA, black or white, in the context of the new South Africa with its ideals of a non-racial country, proved elusive. All the black RCSA synods, as already observed, hoped for a situation in which their churches would also have full involvement in the affairs of theological training, whether at HTS or TSP. The involvement of churches not only implied that these churches wanted to be accommodated in the running of the school, but also that they would be actively involved in teaching - which would imply appointment of black professors. In the initial stages, the unity proved elusive because of the unwillingness of the board of curators of TSP, which was predominately white, to solidify that unity by appointing black professors or lecturers, instead of simply having a few representatives on the curators' board.

In 2000 PU for CHE, in line with the Employment Equity Act, made funds available outside the normal faculty budget in order to enable the university to appoint potential candidates from the previously disadvantaged groups. In the Department of Theology, this opportunity was seized in preparation for posts that will be vacant in two and five years in Missiology and Practical Theology respectively. The 'Affirmative Action Posts' presented an opportunity for the RCSA to begin addressing a long overdue need for the appointment of black professors. However, the appointment process would be riddled with controversies, both internally and externally. This article will only deal with the external controversies, as the internal controversies arose within the selection committee that handled the appointment process.

The 'Affirmative Action Posts' were open for candidates from both black synods of the RCSA and not limited to one of the synods. The deputies of the RCSAMNS and RCSASNS, who were part of the broad curators' board, were notified of the positions. The positions were advertised and notices were sent to candidates who qualified by either holding a master's degree or being in the process of earning one. The RCSAMNS, which had no sitting since 1994, did not endorse any particular candidate for the positions. Thus, within this synod the process was open for any suitable candidate to apply for any of the two positions. The RCSASNS (2000:18, Art. 16.4.4 \& 16.4.5), on the other hand, took a decision to appoint candidates to apply for the posts as follows: 'Synod selects two ministers and encourages their church councils to allow them to apply for these posts', and 'Synod accepts the names of the following ministers as the ones to apply for these posts: Missiology (Rev. AE Liphadzi) and Practical Theology (Rev. Dr Phaswana)'. The two positions, inasmuch as they were university positions, were also church positions, as only candidates from the black RCSA were considered for the two positions. In addition, the involvement of the board of curators at TSP was not limited to being recipients of information regarding a university process in which they had no say. It is for this reason that some of the members of the board of curators were also part of the selection committee that would be responsible for the appointments.

Consequently, five candidates, all from the black RCSA, who applied with or without the endorsement of their respective synods, were interviewed for the positions - two candidates from the RCSAMNS and three from the RCSASNS. On 12 March 2001, the selection committee appointed Reverends T.D. Mashau for Missiology and R.S. Letšosa for Practical Theology.

The RCSASNS, which had put forward names of its preferred candidates for appointment for the position, was met with disappointment as none of their candidates was appointed. Regarding the RCSASNS and the capacity building posts, Baloyi (2011) writes:

They [RCSASNS] thought that they should own the capacitybuilding posts made available by the University, although they did not have people who academically qualified to take those positions at that point. That is why after their candidates failed the interviews (one from the camp of non-favourites passed), their frustrations came to a head. This led to them to withdraw their theological training from the then Potchefstroom University. (p. 6)

Baloyi's loaded statement has significant distortions to it. All the candidates who applied and were interviewed were indeed academically qualified for the positions, including the RCSASNS's preferred candidates. The two candidates who were appointed in the positions had master's degrees, as did the RCSASNS's preferred candidates. To clear the myth that the RCSASNS's preferred candidates were not academically qualified, it is also worthy to note that the RCSASNS's preferred candidates both held master's degrees from Calvin Theological Seminary, whereas the candidates who were finally appointed for the posts were both (recent) graduates from TSP. In addition, T.D. Mashau, who was appointed for one of the positions, also came from the synod that Baloyi 
regards as having no qualified candidates. Furthermore, to regard the process as a matter of pass or fail as though the candidates were writing an exam, is further from the truth, as is clear from the brief from the Faculty of Theology, which sought to explain the process followed in the appointments. The selection of candidates was ultimately done through a ballot - the one who received the most votes was appointed in the post; it was not a matter of pass or fail (see RCSASNS 2001:28-30).

In the view of this author, the RCSASNS's error in judgement was in the following:

1. Firstly, the RCSASNS limited itself by selecting 'preferred candidates' for the positions instead of encouraging all who had the necessary qualifications to apply. This made room for external influence to penetrate the synod and to encourage others to go against the decision of the synod.

2. Secondly, it was an error of judgement for the RCSASNS to hold the view that only candidates from their churches should be appointed for the positions. The RCSASNS was not the only Black synod with interest in theological training - the RCSAMNS also had a vested interest in theological training and there was no reason for it to hold the short end of the stick.

The RCSASNS regarded the appointment process to be fraught with 'serious irregularities' and thereby adding to the frustrations that the synod had been having since its involvement at TSP (see RCSASNS 2001:51). It is not necessary for this article to deal with those irregularities. Important is to note that what transpired with regard to the 'Affirmative Action Posts', or the so-called 'Capacity Building Posts', eventually led the RCSASNS to take the following reactionary decisions, amongst others (see RCSASNS 2001:51-52):

- Re-establish the RCSASNS' own theological seminary by January 2002.

- Withdraw its curators from the board of curators of TSP.

- Attend only ad hoc meetings if the synod's representatives were required.

The decision of the RCSASNS to re-establish Heidelberg in principle was another blow to the attempts to have centralised theological training. Baloyi (2011) claims that the RCSASNS' decision to re-establish its seminary amounted to the withdrawal from the process of unity. On the contrary, the situation within the RCSA since the early 1990s was one of multiple theological institutions operating independent of each other, and this was more so within the RCSAMNS. There was nothing stopping any synod from having its own theological institution or having multiple theological institutions in its service, whether own initiated or otherwise. The breakdown in the unity process between the RCSASNS and the other synods was not solely influenced by the theological training factor. Unity talks proceeded amongst the three synods. However, the talks were more fruitful between the RCSAMNS and the GKSA, which eventually led to the merger of the two synods in 2009. This, in turn, led the new formation to proceed to declare itself a General Synod of the Reformed Church in South Africa ${ }^{17}$ (Algemene Sinode van die Gereformeerde Kerk in Suid-Afrika. In 2012, the General Synod of GKSA proceeded further to terminate structural unity with the RCSASNS.

With the decision to re-establish Heidelberg, it appeared as if SteveBiko's (1987:97) words, 'Blackman, you are on yourown', had finally captivated the hearts of those in the RCSASNS. However, this was not the case. Heidelberg was re-established only in principle. Beginning in 2002, the RCSASNS started to send its students to the University of Pretoria (UP). Thus, with the students receiving their theological training at the UP, Heidelberg functioned as the church's wing to provide 'church-own programmes' for ministerial formation. The training model at UP allows for the faculty of theology at the UP to offer the academic programme, whilst the associated churches can provide training for ministerial formation, which is not part of the academic programme (see Wethmar 2000:425). In the UP model, students receive their training in an ecumenical faculty in which theology is practised in a dialogical relationship by the associated denominations (see Wethmar 2000:426-427). However, from 2002 to date, the RCSASNS has yet to formalise its relationship with the Faculty of Theology at the UP by becoming a partner church. The hope within the RCSASNS is for Heidelberg to continue to develop and to have its own accredited programme, which will be able to serve the needs of their churches.

In the context of the RCSASNS, whilst Heidelberg is the church's own initiated programme, it is however not the sole acknowledged programme. The Classis Tshwane, which forms part of the RCSASNS, has historical ties and a current relationship with Mukhanyo Theological College. Therefore, some of the students of these churches are trained at Mukhanyo Theological College, whilst others are being trained at the UP and Heidelberg. Thus, even with the RCSASNS, there is currently no centralised theological training. It remains to be seen how this synod will handle this situation of multiple theological training centres that are serving the churches in its circle.

\section{Way forward}

The status quo in the RCSA church family is that there are two general synods: Die Algemene Sinode van die GKSA ${ }^{18}$ and the General Synod of the GKSA (Soutpansberg) - this is consequent to the unification of GKSA and RCSAMNS in 2009 and the RCSASNS's decision in its 2014 synod to also regard itself as a general synod. By declaring themselves

17. It will from now on be referred to as the General Synod of GKSA.

18.Following the successful unity talks between GKSA and the RCSAMNS, the two synods merged in 2009 and proceeded to regard the new formation as a General Synod of the Reformed Church in South Africa (Algemene Sinode van die Gereformeerde Kerk in Suid-Afrika). The new formation partly brought to realisation the 1997 decision of the RCSAMNS for the RCSA to be unified alon realisation the 1997 decision of the RCSAMNS for the RCSA to be unified along geographical lines (see RCSAMNS 1997, Art 46). In 1997 when the decision was taken the RCSAMNS intention was to disband on its next synod meeting. However, the dream of a unified RCSA was only realised 12 years later. Thus, 2009 was significant moment in the history of the RCSA as the racial divide that had existed since 1963 was again overcome. The initial overcoming of the racial divide was when the RCSASKNS disbanded in 1990 and joined the structures of the GKSA. However, the synodic divide is yet to be fully overcome. 
general synods, these two synods effectively terminated their structural unity. These terminations of structural unity reflect a deeper problem within this church circle - true reconciliation and true unity is yet to be achieved.

The state of affairs within the RCSA is one that reveals systematic failure in achieving true unity. The parting of ways on theological training and at the synod level reveal the colonial-apartheid baggage that is still weighing heavy on the RCSA 20 years into the new South Africa. In terms of moving forward, the two synods have to heed the biblical call of reconciliation. It would also be worthwhile to heed the message of reconciliation as captured in the Belhar Confession, which originated in the context of struggle within reformed tradition in South Africa (URCSA 2008):

Christ's work of reconciliation is made manifest in the church as the community of believers who have been reconciled with God and with one another (Eph. 2:11-22); that unity is, therefore, both a gift and an obligation for the church of Jesus Christ; [...] that this unity must become visible so that the world may believe that separation, enmity and hatred between people and groups is sin which Christ has already conquered, and accordingly that anything which threatens this unity may have no place in the church and must be resisted (Joh 17:10-13).

They must also (URCSA 2008):

... reject any doctrine which absolutizes either natural diversity or the sinful separation of people in such a way that this absolutization hinders or breaks the visible and active unity of the church, or even leads to the establishment of a separate church formation.

In this author's view, discussions of theological training and synod restructuring in the racially divided RCSA would have been more productive if they had been done in the context of the General Synod of the GKSA. It may even be contended that the last legitimate General Synod of the GKSA was in 1992, and it is that one that remains the broadest church structure in this context. However, it is highly unlikely that a legitimate General Synod of the GKSA would ever be convened again now that there are two general synods. This, however, should not breed a sense of hopelessness.

The two general assemblies are capable, through God's grace, of taking bold steps towards reconciliation and unity. The church has been entrusted with the message of reconciliation - not simply for her to teach reconciliation to others, but also to set an example of reconciliation (2 Cor 5:19-21). When God's people choose to reconcile with each other by choosing peace and unity with each other, freedom and hope are actualised in their current experiences. The words of Moses, when he attempted to reconcile the two Israelites who were fighting each other, are relevant in this context (Ac 7:26): 'Men, you are brothers; why do you want to hurt each other?' In the current context, reconciliation can be started by developing ecumenical relations between the two synods. From this ecumenical relation perhaps fresh formal unity talks may be reignited to overcome the current divide, which owes its origin to the apartheid system that resulted in a racialised establishment of synods. It is in attending to the root of the problem that sustainable peace and unity can be achieved. This would perhaps eventually lead to a formation of a new General Synod of the GKSA/RCSA.

The pursuit for unity between the two general synods does not have to imply one theological institution. As is the case in both synods, there is continuing existence of multiple theological institutions that are servicing the churches in their circles. However, the two general synods will have to find other means to counter the historical injustices and to avoid perpetuating the structures of injustice as they seek harmony amongst the separate theological institutions.

\section{Conclusion}

This analysis of the history of theological training in the black RCSA will hopefully contribute towards the understanding of the challenges within the RCSA and also stimulate those from the black RCSA to dig deep and start writing their own stories - both good and bad.

\section{Acknowledgements Competing interests}

The author declares that he has no financial or personal relationship(s) that may have inappropriately influenced him in writing this article.

\section{References}

Baloyi, M.E., 2010, 'The "sustentasie" problem in the Reformed churches in South Africa: Unmasking the dilemma facing Black theologians', Scriptura 105, 421-433. http://dx.doi.org/10.7833/105-0-154

Baloyi, M.E., 2011, "Church unity and justice in the "Gereformeerde Kerke" in South Africa: Perspectives from Soutpansberg Synod between 2003 and 2008', Studia Historiae Ecclessiasticae 37(1), viewed 26 August 2014, from http://uir.unisa. ac.za/handle/10500/4633

Biko, S., 1987, I write what I like, Cox \& Wyman Ltd, Reading.

Boesak, A., 1976 Farewell to innocence: A socio-ethical study on Black theology and Black power, J.H. Kok, Kampen.

Boesak, A., 2014, Dare we speak of hope, Eerdmans, Grand Rapids.

Botha, L.J., 1994, 'Die HTS in historiese perspektief', in HTS, Hammanskraal Teologiese Skool van die Gereformeerde Kerke in Suid-Afrika: The unfolding of Your words gives light 1962-1994, bl. 3-8, Hammanskraal Teologiese Skool, Hammanskraal.

Brunsdon, A. \& Van der Merwe, S., 2013, 'From Mojadi to Mafikeng: Notes on the newfound Department of Theology', Studia Historiae Ecclesiasticae 39(1), viewed 28 January 2013, from http://uir.unisa.ac.

Buys, F., 1998, 'Die bydrae van prof. J.A. van Rooy in kerk, koninkryk, sending en teologie', In Die Skriflig 32(3), 253-258. http://dx.doi.org/10.4102/ids.v32i3.1642

Cronje, J.M., 1982, Born to witness: A concise history of the churches born out of the mission work of the Dutch Reformed Church (Nederduitse Gereformeerde Kerk) of South Africa, NG Kerkboekhandel, Pretoria.

De Gruchy, J.W., 2005, The church struggle in South Africa, SCM Press, London.

De Haan, M.J., 2010, 'Mission on the margin: A case study on Reformed mission prospects in Enkumane, KwaZulu-Natal', PhD dissertation, School of Religion and Theology, University of KwaZulu-Natal.

Denis, P., 2010, 'Seminary networks and Black consciousness in South Africa in the 1970s', South African Historical Journal 62(1), 162-182. http://dx.doi. org/10.1080/02582471003778417

Du Plessis, H., 1959, 'Gereformeerde Kerk en die Sending,' in S. Du Toit, K.S. Van Wyk de Vries, W.J. Snyman, H.J.J. Bingle, D.W. Kruger, P. Van Straten, et al. (eds.), Die Gereformeerde Kerk in Suid-Afrika 1859-1959: Gedenkboek by geleentheid van die eeufees, bl. 121-131, Die Kerkblad, Potchefstroom.

Du Plooy, A. le R., 2003, 'Die Gereformeerde Kerke in Suid-Afrika 1859-2002: Die vervulling van ' $n$ roeping in belang van die koninkryk van God?', In die Skriflig 37(3), 485-504. http://dx.doi.org/10.4102/ids.v37i3.479 
Dutch Reformed Church, 1976a, Human relations and South African scene in the light of Scripture, D.R. Church Publishers, Cape Town.

Dutch Reformed Church, 1976b, Reply of the Dutch Reformed Church to the report of the Reformed churches in the Netherlands in connection with the programme to combat racism, D.R. Church Publishers, Cape Town.

Gerhart, G.M., 1999, Black power in South Africa: The evolution of an ideology Greenberg, Los Angeles.

Giliomee, H., 2003, The Afrikaners: Biography of a people, University of Virginia Press, Charlottesville.

GKSA (Gereformeerde Kerke in Suid-Afrika), 1949, Handelinge van die dertigste Sinodale vergadering van die GKSA, Admin Buro, Potchefstroom.

GKSA, 1953, Die sending van die Gereformeerde Kerk in Suid-Afrika: 'n Historiese oorsig, saamgestel in opdrag van di Sinodale deputaatskap vir die sending, GKSA Potchefstroom.

GKSA, 1961, Handelinge van die vier-en-dertigste Sinodale vergadering van die GKSA, Admin Buro, Potchefstroom.

GKSA, 1962, Almanak van die Gereformeerde Kerke Suid-Afrika onder nie-blankes, GKSA, Potchefstroom.

GKSA, 1964, Handelinge van die vyf-en-dertigste Sinodale vergadering van die GKSA, Admin Buro, Potchefstroom.

GKSA, 1967, Handelinge van die ses-en-dertigste Sinodale vergadering van die GKSA Potch Herald, Potchefstroom.

GKSA, 1973, Besluite van die nasionale sinode van die Gereformeerde Kerk in S.A. insake sending- en aanverwante sake 1859-1973, Potchefstroom, Pro Rege.

GKSA, 1978, Almanak van die Gereformeerde Kerke in Suidelike Afrika Sinodes: Middellande, Soutpansberg, en Kleurlinge, GKSA, Potchefstroom.

GKSA, 1991, Handeling van die vier-en-veertigste nasionale sinode GKSA, Potch Herald, Potchefstroom.

HTS (Hammanskraal Teologiese Skool), 1959, Jubileum Jaarblad: Die Hammanskraalse Teologiese Skool van die Gereformeerde Kerk in Suid-Afrika, Mbeu Sendingboekwinkel, Sibasa.

HTS, 1994, Hammanskraal Teologiese Skool van die Gereformeerde Kerke in Suid-Afrika: The unfolding of Your words gives light 1962-1994, HTS, Hammanskraal.

Landman, W.A., 1968, A plea for understanding: A reply to the Reformed Church in America, D.R. Publishers, Cape Town.

Lategan, B.C., 1999, 'Reading the Letter to the Galatians from an apartheid and a post-apartheid perspective', in I.R. Kitzberger (ed.), The personal voice in Biblical interpretation, pp. 128-139, Routledge, London.

Mandiwana, T.A., 1983, 'Droom en werklikheid', In die Skriflig 17, 54-57.

Mashau, T.D., 2003, 'Africanisation of Christianity and theology: A Reformational perspective', Journal of Theology and Religion in Africa 27 (1), 123-143.

Mashau, T.D., 2004, 'Hugo du Plessis' contribution to the Reformed churches' struggle for a relevant mission and missiology', PhD Dissertation, School of Ecclesiastical Sciences, Potchefstroom University.

Mothlabi, M.G.B., 2005, 'Black theology in South Africa: An autobiographical reflection', Studia Historiae Ecclessiasticae 31(2), viewed 06 October 2014, from http://uir.unisa.ac.za/handle/10500/4351
Mutavhatsindi, M.A. \& Meiring P.G.J., 2014, 'Church planting in South Africa: The role of the Reformed Church Tshiawelo', Verbum et Ecclesia 35(1), viewed 30 September 2014, from http://www.ve.org.za/index.php/VE/article/view/424/1889

RCSAMNS (Reformed Church in South Africa Midlands National Synod), 1983, Acts of the 11th Synod of the Midlands Reformed Church, Unpublished.

RCSAMNS, 1987, Acts of the 13th Synod of the Midlands Reformed Church, Unpublished. RCSAMNS, 1989, Acts of the 14th Synod of the Midlands Reformed Church, Unpublished. RCSAMNS, 1991, Acts of the 15th Synod of the Midlands Reformed Church, Unpublished. RCSAMNS, 1994, Acts of the 16th Synod of the Midlands Reformed Church, Unpublished. RCSAMNS, 1997, Acts of the 17th Synod of the Midlands Reformed Church, Unpublished. RCSAMNS, 2004, Acts of the 18th Synod of the Midlands Reformed Church, Unpublished. RCSASKNS, 1982, Handelinge van die Sinodale vergadering van die Suidland GKSA, Unpublished.

RCSASKNS, 1985, Handelinge van die Sinodale vergadering van die Suidland GKSA, Unpublished.

RCSASNS (Reformed Church in South Africa Soutpansberg National Synod), 1968, Acts of the Synod, Unpublished.

RCSASNS, 1989, Acts of the Synod Soutpansberg Reformed Church, Unpublished. RCSASNS, 1990, Acts of the Synod Soutpansberg Reformed Church, Unpublished. RCSASNS, 2000, Acts of the Synod Soutpansberg Reformed Church, Unpublished. RCSASNS, 2001, Acts of the Synod, Unpublished.

Stavast, L.H., 1973, 'Die nuwe teologie', in HTS, Jubileum Jaarblad: Die Hammanskraalse Teologiese Skool van die Gereformeerde Kerk in Suid-Afrika, pp. 6-21, Mbeu Sendingboekwinkel, Sibasa.

URCSA (The Uniting Reformed Church in Southern Africa), 2008, Belhar Confession (English translation as adopted by the URCSA synod in 2008), viewed 21 January 2015, from http://www.ngkerk.org.za/vgksa/documents/The $\% 20$ Belhar $\% 20$ Confession.pdf

Van Wyk, J.H., 1988, 'Kerkeenheid: 'n Perspektief op die verhoudinge in die Gereformeerde Kerke in Suidelike Afrika', In Die Skriflig 22, 16-32.

Van Rooy, K., 1990, 'Gereformeerde teologiese opleiding vir Afrika in die een-entwintigste eeu', In Die Skriflig 24(3), 283-294.

Villa-Vicencio, C., 1986, Trapped in apartheid: A socio-theological history of the English-speaking churches, David Philip Publisher/Orbis Books, Cape Town/New York.

Vonkeman, J., 1983, 'Die droom van 'n teologiese opleiding', In die Skriflig 17, 42-53.

Vosloo, R., 2013, 'Remembering the role of the Reformed churches in the struggle for justice in South Africa (1960-1990): Some remarks on the promise and pitfalls of memory and historiography', in M-A. Plaatjies-Van Huffel \& R. Vosloo (eds.), Reformed churches in South Africa and the struggle for justice: Remembering 1960-1990, pp. 15-25, SUN Press, Stellenbosch.

Wethmar, C.J., 2000, 'Theological education in an ecumenical context: Principles and procedures of the Pretoria model', Skrif en Kerk 21 (2), 416-428.

Wielenga, B., 2004, 'Reformed missionary work at Richmond (KZN): A historical analysis of its Dutch roots', In die Skriflig 38(1), 107-124. http://dx.doi. org/10.4102/ids.v38i1.422 